\title{
CORRELATION OF THE PALEOGENE AND NEOGENE DEPOSITS FROM NORTHERN TRANSYLVANIA
}

\author{
NICOLAE MÉSZÁROS
}

\begin{abstract}
The study was concentrated on the Paleogene and Neogene deposits from the border of the Gilău Mountains, east Meseş Mountains, south of Tiicău and Preluca Massifs, the Transcarpathian flysh, as well as those from of south Rodna Mountains. The formations are made up of continental (including fluvial and lacustrine) and normal marine deposits. Based on the nannoplancton data, these were compared to those of the Transcarpathian flysch. In the case of the marine deposits, 5 sedimentation cycles were separated. The last cycle belongs to the Badenian, marked by a general transgression, represented by conglomerates and marls in the base allowed by Dej Tuff and salt deposits. Starting with the Badenian, the Transylvanian Depression evolved as a unitary basin.
\end{abstract}

KEY WORDS: Transylvanian Depression, lithostratigraphy.

\section{Introduction}

As a collaborator of the Shell Romania Exploration B.V., I prospected a large territory between 1992-1996, starting with the eastern part of the Gilău Mountains (lara area), the northern part of the Gilău Mountains and the eastern part of the Vlădeasa Mountains (Huedin), the eastern part of the Meseş Mountains, the southern side of from the Tiicău and Preluca Massifs, as well as Transcarpathian flysh area (Sălăuța Valley), the Bârgăului Mountains and the southern slope of the Rodnei Mountains. 120 long profiles and several hundreds of sections and outcrops were studied. In the same time, a part of showing the lithologic characters of several stratigraphic units, the lithologic variations were followed laterally and vertically, and the thickness and the age of the deposits was determined based on nannoplancton assemblages.

Depending on the paleoenvironment, these units belong either to the epicontinental domain, or to the Transcarpathian flysch. We managed to separate fluvio-lacustrine deposits and marsh deposits. Lagunar deposits of gypsum and alabaster can be distinguished, as well as normal salinity deposits. The Transcarpathian flysch deposits have on the whole a marine character.

\section{Correlations}

Five lithostratigraphic units were separated (sedimentation cycles):

*Department of Geology-Paleontology, Babeş-Bolyai University, 1 Kogălniceanu str. RO-3400, Cluj-Napoca, Romania 
The Jibou Formation (ex - lower variegated clays - Koch, 1894; Hofmann, 1879; lower variegated complex - Răileanu \& Saulea, 1956). This is a 1500 thick fluvio-lacustrine unit, having a main lacustrine interbedding of the Rona Member (ex - lower freshwater level - Koch, 1894) at Jibou, separating the formation into three parts. The Rona Member is made up of limestone, marls, clays with characeans (Baciu, 1997), mollusks (Mészáros, 1991) and vertebrate (Gheerbrant et al., 1999) remains.

The corresponding unit in the Transcarpathian flysch is the Sălăuța Formation, made up especially of sandstones and conglomerates. The two nannoplancton levels (NP 8 and NP 14), indicate the Paleocene, Early Eocene and Early Lutetian age of these deposits.

Early marine transgression of the Late Lutetian determined the deposition of the Călata Group (Rusu, 1995; Filipescu, 1997) (ex - Lower marine series Răileanu \& Saulea, 1956; the Rakoczi Group - Mészáros, 1991).

This group includes the Foidaş Formation (Mészáros \& Moisescu, 1991; Pion, 1968) in the base, a lagunar unit with gypsum (ex - lower gypsum of the Anomia limestone - Koch, 1894). This is followed by the Căpuş Formation (ex Ostrea level, Marly-limestones with Ostrea, lower marls with mollusks, lower level with "striata", "perfforatus" level, upper "striatus" level, medium marls with molluscs, upper Ostrea level, marls and limestone with nummulites and mollusks - Koch, 1894). All these banks and levels were included into the Inucu and Văleni members. NP 15-16 and 17 nannozones are characteristic to these deposits.

The following Mortănuşa Formation (ex - grey marly-clay horizont - Koch, 1894) is made up of clays and marls and presents a regressive character in the upper third, where it becomes extremely sandy. There we can trace the boundary between NP 17 and 18 zones, that is between Lutetian and Bartonian (Mészáros, 1989; Bombiță, 1963).

The equivalent of the Foidaş, Căpuşu and Mortănuşa formations in the Transcarpathian Basin is the Prislop Formation (Mészáros, 1993).

The Călata Group ends with the Viştea Limestone (Rusu, 1995) (ex Lower coarse limestone - Koch, 1894) and the Rakoczi Sandstone.

Due to the pre-Pirenian movements (Dudich \& Mészáros, 1963), the continental environment established again and thus the Valea Nadăşului Formation was deposited (ex - upper variegated clay series Koch, 1894).

The equivalent of these deposits in the Transcarpathian flysch, is the lower part of the Vaser Formation (Mészáros, 1993).

Another marine transgresion was responsible for the formation of the following unit, the Turea Group (Rusu, 1995) (ex - upper marine series - Răileanu \& Saulea, 1956). This group starts with the lagunar Jebucu Formations (Moisescu, 1989) (ex - upper gypsum - Koch, 1894) The following formation is the Cluj Limestone (ex- upper coarse limestone - Koch, 1894). The deepening of the sea permitted the deposition of the Brebi Formation (ex - "intermedia" and bryozoan beds - Koch, 1894), made up of marls containing Nummulites fabianii. In this unit, the Gigantostrea gigantea level marks the Eocene-Oligocene boundary (Mészáros, et al., 1989) or the boundary between the nannoplancton zones NP 21-22. In the Transcarpatian area corresponding to Jebucu, Cluj and Brebi formations, was 
formed the upper part of the Vaser Formation.

The Mera Formation (Mészáros, et al., 1989) lays on the top of the Brebi Formation, having as base the Hoia Limestone, corresponding east of Jibou to the Ciocmani Formation (Hofmann, 1879). In NW of Transylavania we can distinguish a stratigraphic unit containing coal, freshwater mollusks and characeans known as the Curtuiuş Formation (Petrescu \& Mészáros, 1989). All these formations are equivalent to the upper part of the Vaser Formation in the Transcarpathian flysh.

Due to Pirennian movements, a rise produced in NW of Transylvania (Mészáros \& Dudich, 1968), and thus continental deposits belonging to the Moigrad Formation (ex - Ticu beds - Koch, 1894) were deposited. These continental deposits change into marine deposits in the East; there are made up of marly-limestones of the Bizuşa Formation, belonging to zone NP 24. Corresponding to these, the Valea Carelor Formation occurs in the Transcarpathian area.

Over the continental deposits of the Moigrad Formation lay the brackish deposits belonging to the Gruia and Dâncu formations (ex - Cetate beds - Koch, 1894), which change in the East into disodilic shales of Ileanda Formation. In the Transcarpathian area these correspond to bituminous shales with interbedded sandstone of the Birțu Sandstone (Mészáros, 1993).

In the NW of Transylvania the Cuzăplac Formation represents a continental formation, changing in the East into the marine (zone NP 25) Cubleşu Formation, which changes further East into Var Sandtone. On their top occur the continental deposits of the Sâncraiu Almaşului Formation which is Early Miocene in age.

Another transgression produced the deposition of the Coruş Formation. South of Preluca, the Var Formation, Sânmihaiu Almaşului and Coruş Formations change into the Buzaş Sandstone (Rusu, 1989) south of Preluca.

The Coruş Formation is covered by the Chechiş Formation, having in base a glauconitic level (NN 3). The Buzaş Formation, together with the Chechiş Formation change into the marls belonging to the Vima Formation (Mészáros, 1993). Inside this we can trace the Oligocene-Miocene boundary (NP 25 - NN 1). Towards the Transcarpathian region, the Vima Formation changes into very thick turbidite deposit belonging to the Borşa Sandstone.

A more than $500 \mathrm{~m}$ thick formation developed over the Chechiş Formation, in Northern Transylvania. It consists of conglomerate and sandstones alternating with clays, marls, sandy marls belonging to the Ottnangian Hida Formation (NN 4).

The Lower Badenian (Moravian) contains at its base the conglomerates of the Ciceu-Giurgeşti Formation (NN 5), which support the Dej Tuff (Popescu, 1975; Mészáros \& Filipescu, 1991), then salt deposits (Wielician).

\section{REFERENCES}

1. Baciu, C., 1997, Câteva specii de carophyte din partea superioară a Calcarului de Rona. Natura Silvanie 1., p. 153 - 161, Jibou.

2. Bombiță, G., 1963, Contrubuții la corelarea Eocenului epicontinental din R. P. România. Ed. Acad. R. S. R., p. 113, Bucureşti.

3. Dudich, E., Mészáros, M., 1963, Über die Verbreitung und Typen der Krustenbewegungen und dees Vulcanismus im Mittel - und Sud-öst Europa am ende des Mitteleozäns. N. Jb. Geol. Paleont. Abh. 1., p. 65 -83, Stuttgart. 
4. Filipescu, S., 1997, Several comments on the nomenclature of the Lithostratigraphic units from Transylvanian Depression. Studia. Univ. "Babeş-Bolyai". Geologia. XLII, 2, p. $83-85$, Cluj-Napoca.

5. Gheerbrant, E.; Codrea, V; Hosu, A; Sen., S.; Guernet, C.; de Lapparent de Broin, F.; \& Riveline, J., 1999, Découverte de vertébrés dans les Calcaires de Rona (Thanétien ou Sparnacien), Transylvanie, Roumanie: les plus anciens mammifères cénozoiques d'Europe Orientale. Eclogae geol. Helvetiae 92 (1999), 517-535, Basel.

6. Hofmann, K., 1879, Jelentés az 1878 nyarán Szilágy megye keleti részében tett földtani részletes fölvételröl. Földt. Közl. IX, 5 - 6, p. 167, Budapest.

7. Koch, A., 1894, Die Tertiarbildungen des Beckens der Siebenbürgischen Landestheile. I. Paleogene. auswirkungen auf die Oligozäne, und in der Nachbargebieten. Acta. Geol. Hung., I Z, p. 263 - 290, Budapest Abth. Herasgegeben von d. Ungar. Geol. Gessell., p. 223, Budapest.

8. Mészáros, N., 1991, Nannoplancton zones in the Miocene deposits of the Transylvanian Basin. I N A Newsletter 13/2 Prague. Abstr., p. 58-60, London.

9. Mészáros, N., Moisescu, V., Rusu, A., 1989, The Merian, a new substage of the Mesogean Oligocene. The Oligocene of the Transylvanian Basin, p. 31 - 54, ClujNapoca.

10. Mészáros, N., Dudich, E., 1989, Die Typen der pyrenaichen bewegungen an der Eozän/Oligozän - Wende und ihre auswirkungen auf die Oligozäne, und in der Nachbargebieten. Acta. Geol. Hung., I Z, p.236 - 290, Budapest.

11. Mészáros, N., Filipescu, S., 1991, Le nannoplancton du tuf de Dej. The volcanic Tuffs from the Transylvanian Basin. p. 79 - 81, Cluj-Napoca.

12. Mészáros, N., Moisescu, V., 1991, Bréf aperçu des unités Lithostratigraphiques du Paléogène dans le nord-ouest de la Transylvanie. Bull. Inf. Géol. Bass. Paris, 28, p. 31 - 39, Paris.

13. Mészáros, N., 1993, Transylvanian Basin Lithostratigraphic Synopsis, Haga.

14. Pion, N., P., 1968, Observații noi asupra gipsurilor eocene din Bazinul Transilvaniei. D. S. Com. Geol. LIV/1, p. 257 - 262, Bucureşti.

15. Petrescu, I., Mészáros, N., 1989, General approach to the Curtuiuş Beds. The Oligocene of the Transylvanian Basin, p. 87 - 104, Cluj-Napoca.

16. Popescu, Gh., 1975, Études des foraminifères du Miocène inférièur et moyen du nord-ouest de la Transylvanie. Memoriile I. G. G., 23, p. 121, Bucureşti.

17. Răileanu, Gr., Saulea, E., 1956, Paleogenul din regiunea Cluj şi Jibou (N-W Bazinului Transilvaniei). An. Com. Geol. XXIX, p. 271 - 306, Bucureşti.

18. Rusu, A., 1989, Problems of Correlation and Nomenclature Concerning the Oligocene Formations in NW Transylvania. The Oligocene of the Transylvanian Basin, p. 67 78, Cluj-Napoca.

19. Rusu, A., 1995, Eocene Formations in the Călata region (NW Transylvania). A critical review. f. Tect. and eg. Geol., 76, p. 59 - 72, Bucureşti. 